\title{
Article \\ Effect of Forecast Climate Changes on Water Needs of Giant Miscanthus Cultivated in the Kuyavia Region in Poland
}

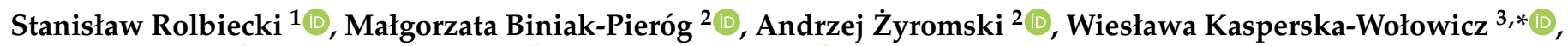 \\ Barbara Jagosz ${ }^{4}$ (D), Piotr Stachowski ${ }^{5}$ (D), Daniel Liberacki ${ }^{5}$ (D) Ewa Kanecka-Geszke ${ }^{3}$, Hicran A. Sadan ${ }^{1}$, \\ Roman Rolbiecki ${ }^{1}$ (D), Ferenc Pal-Fam ${ }^{6}$ (D) and Wiesław Ptach ${ }^{7}$
}

check for updates

Citation: Rolbiecki, S.; Biniak-Pieróg M.; Żyromski, A.; Kasperska-

Wołowicz, W.; Jagosz, B.; Stachowski, P.; Liberacki, D.; Kanecka-Geszke, E.; Sadan, H.A.; Rolbiecki, R.; et al. Effect of Forecast Climate Changes on Water Needs of Giant Miscanthus Cultivated in the Kuyavia Region in Poland. Energies 2021, 14, 6628. https://doi.org/10.3390/en14206628

Academic Editor: Dalia Štreimikienè

Received: 2 September 2021

Accepted: 9 October 2021

Published: 14 October 2021

Publisher's Note: MDPI stays neutral with regard to jurisdictional claims in published maps and institutional affiliations.

Copyright: (c) 2021 by the authors. Licensee MDPI, Basel, Switzerland. This article is an open access article distributed under the terms and conditions of the Creative Commons Attribution (CC BY) license (https:// creativecommons.org/licenses/by/ $4.0 /)$.
1 Department of Agrometeorology, Plant Irrigation and Horticulture, Faculty of Agriculture and Biotechnology, Bydgoszcz University of Science and Technology, 85-029 Bydgoszcz, Poland; rolbs@utp.edu.pl (S.R.); hicran_sadan_76@hotmail.com (H.A.S.); rolbr@utp.edu.pl (R.R.)

2 Department of Environmental Protection and Development, Faculty of Environmental Engineering and Geodesy, Wrocław University of Environmental and Life Sciences, 50-363 Wrocław, Poland; malgorzata.biniak-pierog@upwr.edu.pl (M.B.-P.); andrzej.zyromski@upwr.edu.pl (A.Ż.)

3 Institute of Technology and Life Sciences-National Research Institute, Falenty, 3 Hrabska Avenue, 05-090 Raszyn, Poland; e.kanecka-geszke@itp.edu.pl

4 Department of Plant Biology and Biotechnology, Faculty of Biotechnology and Horticulture, University of Agriculture in Krakow, 31-120 Krakow, Poland; Barbara.Jagosz@urk.edu.pl

5 Department of Land Improvement, Environmental Development and Spatial Management, Faculty of Environmental Engineering and Mechanical Engineering, Poznan University of Life Sciences, 60-649 Poznań, Poland; piotr.stachowski@up.poznan.pl (P.S.); daniel.liberacki@up.poznan.pl (D.L.)

6 Institute of Plant Production, Kaposvár Campus, Hungarian University of Agriculture and Life Sciences, H-7400 Kaposvár, Hungary; Pal-Fam.Ferenc.Istvan@uni-mate.hu

7 Department of Remote Sensing and Environmental Research, Institute of Environmental Engineering, Warsaw University of Life Sciences, 02-776 Warszawa, Poland; wieslaw_ptach@sggw.edu.pl

* Correspondence: w.kasperska-wolowicz@itp.edu.pl

Abstract: Giant miscanthus is a vigorously growing energy plant, popularly used for biofuels production. It is a grass with low soil and water requirements, although its productivity largely depends on complementary irrigation, especially in the first year of cultivation. The aim of the study was to assess the impact of the forecast climate changes, mainly air temperature increase, on the water needs of giant miscanthus during the growing season in 2021-2050 in the Kuyavia region (central Poland). The years 1981-2010 as the reference period were applied. The meteorological data was based on the regional climate change model RM5.1 with boundary conditions from the global ARPEGE model for the SRES A1B emission scenario. Crop evapotranspiration, calculated using the Penman-Monteith method and crop coefficients, was assumed as a measure of water needs. The study results showed that in view of the expected temperature changes, in the forecast period 2021-2050, the giant miscanthus water needs will increase by $10 \%$. The highest monthly increase may occur in August (16\%) and in September (23\%). In the near future, the increase in water needs of giant miscanthus will necessitate the use of supplementary irrigation. Hence the results of this study may contribute to increasing the efficiency of water use, and thus to the rational management of irrigation treatments and plant energy resources in the Kuyavia region.

Keywords: evapotranspiration; irrigation; Miscanthus $\times$ giganteus; precipitation deficit; water requirements

\section{Introduction}

Climate change is one of the greatest threats nowadays for the environment and various sectors of the economy. The industrial revolution, initiated by the discovery of fossil fuels, resulted in the increasing greenhouse gas emissions from year to year, consequently resulting in increase of average temperature values around the globe. Every year in the world about 51 billion greenhouse gases are being produced. It is believed that an increase in mainly $\mathrm{CO} 2$, but also other greenhouse gases, will affect current farming 
systems [1-3]. According to the European Environment Agency [2], global warming may, on the one hand, improve the conditions for growing plants in some parts of northern Europe, but will worsen them for example in southern Europe, contributing to phenomena such as droughts and heat waves. As a consequence, it will result in worsening harvest and increasing production costs.

The more and more frequent years with anomalous air temperatures and precipitation, resulting from the observed climate change, indicate the need for rational water management, which undoubtedly requires a precise identification of the water needs of plants. Kundzewicz and Matczak [4] pointed at-in the climate change projections for Poland-adverse changes in the water budget (evapotranspiration minus precipitation) deficit and water deficits are projected to increase further in the future. In the context of the efficiency of cultivation of energy crops, it is important to recognize the efficiency of water consumption by them [5-8] in relation to the amount of evapotranspiration of these crops. Accurate diagnosis of this process is possible thanks to laborious and cost-intensive field studies conducted with the use of evaporometers or soil lysimeters, or indirect methods of estimating the amounts of evapotranspiration are used [9-13]. Acquiring this knowledge allows to identify periods of increased water demand of plants during the growing season and those periods in which water shortages significantly contribute to the reduction of yields. Due to the fact that in the case of energy crops, the yield is mainly determined by the water factor, in the case of water shortage, the cultivation of plantations becomes economically unjustified. Therefore, it is important to recognize the impact of water deficit on plant growth and development [14-17].

Perennial energy grasses show great resistance to changing climatic conditions. These are used as a renewable source of biomass for both energy and non-energy purposes and ecosystem services, and show great potential to mitigate global warming [18-23]. Miscanthus is one of these plants. The conducted experimental studies show that it has the highest energy value (MJ/ha) among other energy crops and is characterized by the highest energy use efficiency [24]. Hence, it is the subject of many research studies [24-30]. The advantage of miscanthus cultivation is the possibility to establish plantations on areas contaminated by industrial pollution, because it has the ability to absorb heavy metals, remove organic pollutants, enhance carbon deposition, improve the physical and chemical properties of soil and it proves to be an anti-erosion plant [31-38].

The climatic conditions of Poland are conducive to the cultivation of many species of energy plants. The most favorable locations for plantations are the regions of northern and southern Poland, while the least favorable is the central part of Poland, due to the relatively low precipitation during the growing season (at the level of 300-350 mm), and especially in the years of large deficiencies in precipitation, this cultivation may be economically unprofitable [39]. Giant miscanthus (Miscanthus $\times$ giganteus J. M. Greef \& Deuter ex Hodk. \& Renvoize), perennial grass that reaches a height of up to 3-4 $\mathrm{m}$, is one of the popular energy crops in Poland [25,40-42]. It is a species used mostly as raw material for solid biofuels. Giant miscanthus is a plant with the $\mathrm{C} 4$ photosynthesis mechanism, which favors low water consumption per unit of dry mass produced [20,43,44]. According to Van der Veijde, et al. [43] the amount of water required of each kilogram of biomass accumulation is much lower for miscanthus than for maize or sugarcane. This grass is characterized by a rapid growth, and thus a high yield of biomass per unit area. Giant miscanthus is a low-maintenance energy plant that can be grown even on very poor soils, with a very low nutrient content and moisture content [44], although it requires sufficient hydration in the first year of cultivation. According to Matyka and Kus [45] spring frosts can cause damage to root stocks, which results in decreased yields. The water needs of this species can be met by rainfall with an annual total of $600-700 \mathrm{~mm}$ [46]. Although giant miscanthus is a thermophilic species, the sums of temperatures in Polish climate conditions allow for satisfactory yields to be obtained [47].

The objective of the research, in the light of above, was to estimate the impact of projected changes in air temperature on water needs of giant miscanthus for the period 
2021-2050 for one of the main agricultural regions in Poland called Kuyavia (pl. Kujawy). It is situated in Kuyavian-Pomeranian province (pl. kujawsko-pomorskie) in central Poland (central Europe). It belongs to the area of the lowest precipitation totals in Poland, and is the region with the greatest requirements of supplementary irrigation during the growing season. This is confirmed by the studies of long-term fluctuations in rainfall in the years 1931-2000 in this region [48]. Based on the forecast for 2011-2050 years in the studied region-calculated by the regional climate model RM5.1 with boundary values used from global model ARPEGE (fr. Action de Recherche Petite Echelle Grande Echelle)-a decrease in the amounts of rainfall during the growing season by approximately $55 \mathrm{~mm}$ is predicted (compared to 1971-2000 as a reference period). An increase of the mean sum of precipitation in spring months (April-May), slight decrease in June and marked decrease of precipitation in other months (July-September) are predicted in the monthly course of precipitation [49]. The same climate model calculation predicts statistically significant increasing trend of air temperature in April, June, August and in the whole growing season by $0.5-0.7^{\circ} \mathrm{C} \cdot$ decade $^{-1}$ in these months and $0.3{ }^{\circ} \mathrm{C} \cdot$ decade $^{-1}$ in the whole season [50]. The calculations of the giant miscanthus water needs were based on the changes in air temperature observed in the reference years 1981-2010, and made for the period of the highest water needs and intensive growth where supplementary irrigation is required (from the end of May till the end of September) of this species. The results of the current study may contribute to the development of the appropriate management of irrigation treatments and plant energy resources in central Poland.

\section{Materials and Methods}

Water needs of giant miscanthus (Miscanthus $\times$ giganteus J. M. Greef \& Deuter ex Hodk. \& Renvoize) cultivated in the Kuyavia region located in central Poland (central Europe) were calculated for the years 2021-2050 (forecast period). The estimations were carried out for the giant miscanthus period of the highest water needs and intensive growth, from May 21 till September 30. In the study, the forecast values of average monthly air temperature for the Kuyavia region in the years 2021-2050, according to the climate change scenario for Poland IPCC-SRES (Intergovernmental Panel on Climate Change-Special Report on Emissions Scenarios): A1B (balanced scenario) [49,50] were applied. The thirty-year period 1981-2010 was adopted as the reference period, using the values of average monthly air temperature for Kuyavia region according to the measurements of the meteorological station of the Institute of Technology and Life Sciences in Falenty. The region of the Kuyavia is located in central Poland, where there are the highest requirements for supplementary irrigation during the growing season.

Water needs of giant miscanthus were calculated by the method of crop coefficients based on the reference evapotranspiration [51,52]. In this method, the crop water needs are expressed as the potential evapotranspiration (ETp), that is actual evapotranspiration of a given species under conditions of sufficient soil water supply to plants. This depends also on meteorological conditions and plant growth and development stage. The giant miscanthus potential evapotranspiration was calculated using the following Formula (1):

$$
\mathrm{ETp}=\mathrm{ETo} \times \mathrm{kc}
$$

where:

ETp = crop potential evapotranspiration $(\mathrm{mm})$;

ETo = reference evapotranspiration $(\mathrm{mm})$;

$\mathrm{kc}=$ crop coefficient that is the ratio of evapotranspiration measured in conditions of sufficient humidity to the reference evapotranspiration [52].

The values of the crop coefficient for individual months of the giant miscanthus growth in the Kuyavia region are presented in Table 1. The values of kc were elaborated and modified for miscanthus cultivated in conditions of Poland on the basis of Żyromski et al. [9] experiments with energy crops, including miscanthus. They developed empirical indices (coefficients) permitting the estimation of evapotranspiration of giant miscanthus. 
Table 1. Values of the crop coefficient for the Penman-Monteith formula for giant miscanthus cultivated in the Kuyavia region (own elaboration on the basis of Żyromski et al., 2016).

\begin{tabular}{cccccc}
\hline Month & 21-31 May & 1-30 June & 1-31 July & 1-31 August & 1-30 September \\
\hline Crop Coefficient & 0.42 & 0.74 & 0.88 & 0.95 & 1.02 \\
\hline
\end{tabular}

The reference evapotranspiration during the reference period (1981-2010) was determined according to the Penman-Monteith method using the following Formula $(2)[53,54]$ :

$$
\mathrm{ETo}=\mathrm{n} \frac{0.408 \Delta \mathrm{R}_{\mathrm{n}}+\gamma \frac{900}{\mathrm{~T}+273} \mathrm{u}\left(\mathrm{e}_{\mathrm{s}}-\mathrm{e}_{\mathrm{a}}\right)}{\Delta+\gamma(1+0.34 \mathrm{u})}
$$

where:

$\mathrm{ETo}=$ reference evapotranspiration $\left(\mathrm{mm} \mathrm{d}^{-1}\right)$;

$\mathrm{n}=$ number of days;

$\Delta=$ slope vapour pressure curve $\left(\mathrm{kPa}^{\circ} \mathrm{C}^{-1}\right)$;

$\mathrm{R}_{\mathrm{n}}=$ net solar radiation at the crop surface $\left(\mathrm{MJ} \mathrm{m}^{-2} \mathrm{~d}^{-1}\right)$;

$\gamma=$ psychrometric constant $\left(\mathrm{kPa}^{\circ} \mathrm{C}^{-1}\right)$;

$\mathrm{T}=$ air temperature at a height of $2 \mathrm{~m}$ above the ground $\left({ }^{\circ} \mathrm{C}\right) ;$

$\mathrm{u}=$ wind speed at a height of $2 \mathrm{~m}$ above the ground $\left(\mathrm{m} \mathrm{s}^{-1}\right)$;

$\mathrm{e}_{\mathrm{s}}=$ saturation vapour pressure $(\mathrm{kPa})$;

$\mathrm{e}_{\mathrm{a}}=$ actual vapour pressure $(\mathrm{kPa})$.

The reference evapotranspiration in the forecast years 2021-2050 was calculated using linear regression equations between the Penman-Monteith reference evapotranspiration and air temperature. These equations were determined using the data of the reference years 1981-2010. This methodological assumption was applied after Łabędzki, et al. [55], who estimated the reference evapotranspiration according to Penman-Monteith in order to determine the water needs of potato in the years 2021-2050 and 2071-2100.

The results of the study were statistically analyzed by determining the values of mean, maximum, minimum, and median, as well as the standard deviation (SD) and coefficient of variation. Possible trends of the changes in the giant miscanthus water needs in both compared periods (forecast years and reference years) were also calculated by the linear regression analysis, with estimation of the correlation and determination coefficients. The significance of the correlation coefficient, with the sample size $n=30$, was determined for $p=0.05$. According to the confidence interval, the value of the correlation coefficient was significant for $\mathrm{r} p \geq 0.362$ [56].

\section{Results}

Statistical characteristics of the giant miscanthus water needs during the intensive growth season in the reference and forecast years are given in Table 2. In both cases, the strongest differentiation of monthly sums of the giant miscanthus water needs, expressed as the standard deviation, was recorded in the period from 1 June to 31 August. In the forecast period (2021-2050), of these three months, the highest standard deviation value (12.4 mm) was estimated in June, lower $(11.9 \mathrm{~mm})$ in July, and the lowest $(10.4 \mathrm{~mm})$ in August. In the reference period (1981-2010), the SD in monthly sums of the giant miscanthus water needs ranged from 14.7 in July to $10.3 \mathrm{~mm}$ in August. 
Table 2. Statistical characteristics of the giant miscanthus water needs determined as potential evapotranspiration (mm) during the intensive growth season in the reference and forecast years.

\begin{tabular}{|c|c|c|c|c|c|c|}
\hline \multirow{2}{*}{ Characteristic } & \multicolumn{6}{|c|}{ Months } \\
\hline & 21-31 May & 1-30 June & 1-31 July & 1-31 August & 1-30 September & 21 May-30 September \\
\hline \multicolumn{7}{|c|}{ Reference Period 1981-2010 } \\
\hline Mean (mm) & 14 & 79 & 102 & 89 & 52 & 336 \\
\hline Minimum (mm) & 10 & 60 & 75 & 70 & 38 & 277 \\
\hline Maximum (mm) & 17 & 103 & 134 & 111 & 69 & 403 \\
\hline Median (mm) & 14 & 78 & 96 & 89 & 50 & 336 \\
\hline Standard Deviation & 1.6 & 9.7 & 14.7 & 10.3 & 7.7 & 28.8 \\
\hline Coefficient of Variation (\%) & 11.9 & 12.3 & 14.4 & 11.5 & 14.7 & 8.6 \\
\hline \multicolumn{7}{|c|}{ Forecast Period 2021-2050 } \\
\hline Mean $(\mathrm{mm})$ & 13 & 81 & 110 & 103 & 64 & 372 \\
\hline Minimum (mm) & 9 & 58 & 83 & 79 & 53 & 316 \\
\hline Maximum (mm) & 18 & 104 & 132 & 125 & 74 & 433 \\
\hline Median (mm) & 13 & 81 & 110 & 103 & 63 & 374 \\
\hline Standard Deviation & 2.2 & 12.4 & 11.9 & 10.4 & 6.1 & 30.7 \\
\hline Coefficient of Variation (\%) & 17.5 & 15.4 & 10.8 & 10.1 & 9.5 & 8.3 \\
\hline
\end{tabular}

Relative differentiation of the giant miscanthus water needs during the analyzed season of growth, expressed by the coefficient of variation, amounted to $8.3 \%$ and $8.6 \%$ in the forecast and reference periods, respectively. A very high relative differentiation (17.5\%) of the giant miscanthus water needs was recorded at the beginning of the analyzed season, i.e., in the third decade of May. High monthly coefficient of variation values were found in June $(15.4 \%)$ in the forecast period, as well as in July $(14.4 \%)$ and September $(14.7 \%)$ in the reference period.

Table 3 presents the equations of linear regression tendency in temporal variability of the giant miscanthus water needs, which were calculated for the reference and forecast periods. In the forecast period (2021-2050), throughout the growing season, except in September, monthly water needs expressed as the potential evapotranspiration showed an upward tendency. In the reference period (1981-2010), an upward trend in the water needs of giant miscanthus was observed only in June and September.

Table 3. Time trend equations of the water needs $(\mathrm{mm})$ of giant miscanthus during its specific spells of growth in the reference and forecast years.

\begin{tabular}{ccc}
\hline Spell of Growth & Reference Period 1981-2010 & Forecast Period 2021-2050 \\
\hline 21-31 May & $\mathrm{y}=-0.027 \mathrm{x}+14.143$ & $\mathrm{y}=0.0382 \mathrm{x}+12.154$ \\
1-30 June & $\mathrm{y}=0.2045 \mathrm{x}+75.967$ & $\mathrm{y}=0.2923 \mathrm{x}+76.257$ \\
1-31 July & $\mathrm{y}=-0.0564 \mathrm{x}+102.8$ & $\mathrm{y}=0.0638 \mathrm{x}+109.36$ \\
1-31 August & $\mathrm{y}=-0.1369 \mathrm{x}+91.39$ & $\mathrm{y}=0.4637 \mathrm{x}+96.177 *$ \\
1-30 September & $\mathrm{y}=0.0125 \mathrm{x}+51.971$ & $\mathrm{y}=-0.0699 \mathrm{x}+65.351$ \\
1 June-31 August & $\mathrm{y}=0.0113 \mathrm{x}+270.16$ & $\mathrm{y}=0.8197 \mathrm{x}+281.79$ \\
21 May-30 September & $\mathrm{y}=-0.0032 \mathrm{x}+336.27$ & $\mathrm{y}=0.788 \mathrm{x}+359.3$ \\
\hline
\end{tabular}

${ }^{*}$ Statistical significance at $p=0.05$.

The values of the coefficient of determination and the tendencies in giant miscanthus water needs changes per decade, i.e., per 10 years, are presented in Table 4 . In the considered thirty-year forecast period (2021-2050), the seasonal water needs of giant miscanthus during its season of analysis, i.e., from 21 May to 30 September, increased by $7.9 \mathrm{~mm}$ per decade. The water needs increased the most in August (4.6 mm per decade). Moreover, only in August the tendency of changes in the crop water needs was significant (Tables 3 and 4, Figure 1). In general, in June, July, and August, the giant miscanthus water needs showed an upward trend in the forecasted thirty-year period (2021-2050) amounting to $8.2 \mathrm{~mm}$ per ten years. 
Table 4. The coefficient of determination and the tendency of changes in the giant miscanthus water needs during its specific spells of growth in the reference and forecast years.

\begin{tabular}{ccccc}
\hline & \multicolumn{2}{c}{ Reference Period 1981-2010 } & \multicolumn{2}{c}{ Forecast Period 2021-2050 } \\
\cline { 2 - 5 } Spell of Growth & $\begin{array}{c}\text { Coefficient } \\
\text { of Determination } \\
\mathbf{R}^{\mathbf{2}}\end{array}$ & $\begin{array}{c}\text { Trend of Changes } \\
\text { in Water Needs } \\
(\mathbf{m m} \text { decade } \mathbf{- 1})\end{array}$ & $\begin{array}{c}\text { Coefficient } \\
\text { of Determination } \\
\mathbf{R}^{\mathbf{2}}\end{array}$ & $\begin{array}{c}\text { Trend of Changes } \\
\text { in Water Needs } \\
\text { (mm decade }\end{array}$ \\
\hline 21-31 May & 0.0205 & -0.3 & 0.0228 & 0.4 \\
1-30 June & 0.0331 & 2.0 & 0.0429 & 2.9 \\
1-31 July & 0.0011 & -0.6 & 0.0022 & 0.6 \\
1-31 August & 0.0133 & -1.4 & $0.154 *$ & 4.6 \\
1-30 September & 0.0002 & 0.1 & 0.0101 & -0.7 \\
1 June-31 August & $1 \times 10^{-5}$ & 0.1 & 0.0777 & 8.2 \\
21 May-30 September & $9 \times 10^{-7}$ & 0.0 & 0.051 & 7.9 \\
\hline
\end{tabular}

$*$ Statistical significant at $p=0.05$.

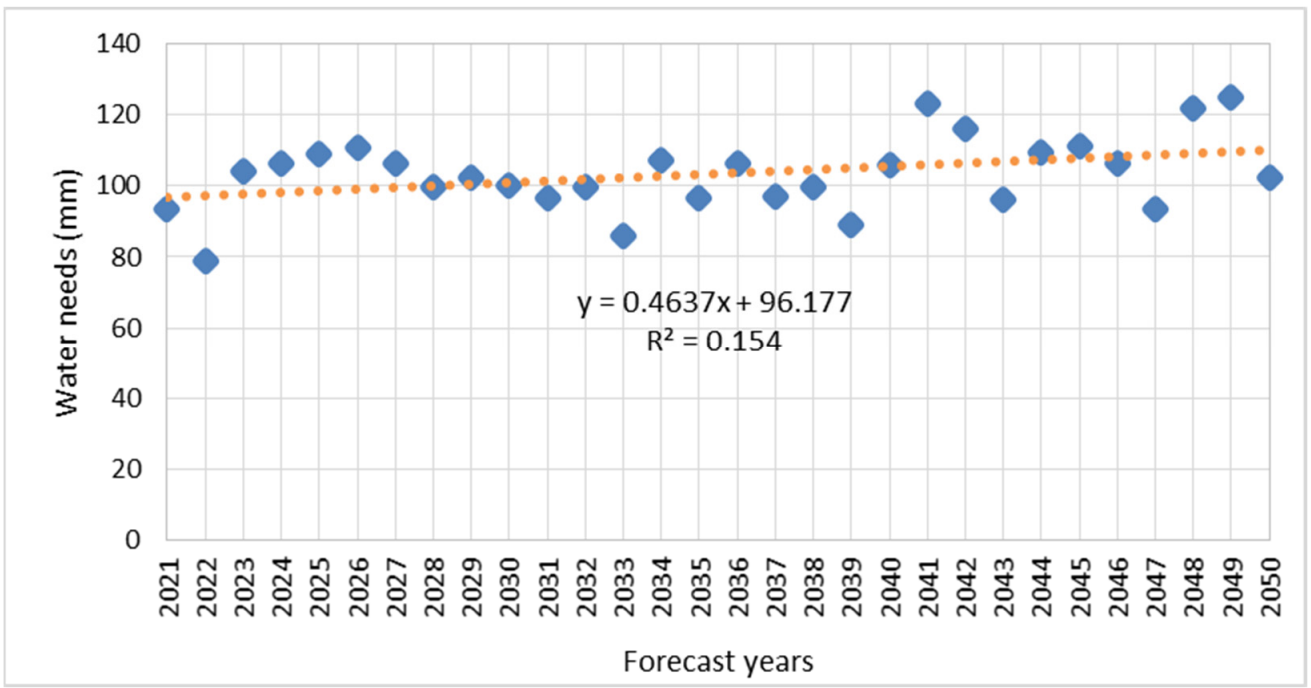

Figure 1. Predicted amounts of the giant miscanthus water needs in August, statistically significant, in the forecast years (2021-2050).

The highest daily water needs of giant miscanthus in the forecast period (2021-2050) were recorded in July and amounted to $3.3 \mathrm{~mm}$ and $3.5 \mathrm{~mm}$ in the reference and forecast period, respectively (Figure 2). Furthermore, high daily water needs were found in August and June.

According to the results of the study, in the 30-year forecast period 2021-2050, the water requirements in the giant miscanthus cultivation will clearly increase (Figure 3 ). The values of water needs of giant miscanthus during its specific spells of growth in the reference and forecast years are presented in Table 5. It is expected that in the years 20212050, the giant miscanthus water needs during the intensive growth season (from 21 May to 30 September) will increase by over $10 \%$, from $336 \mathrm{~mm}$ to $371 \mathrm{~mm}$ (Figure 3). Due to the forecast temperature changes, the highest monthly increase in the water needs by $14 \mathrm{~mm}$, i.e., $16 \%$ may occur in August, and by $12 \mathrm{~mm}$, i.e., $23 \%$ in September (Table 5). 


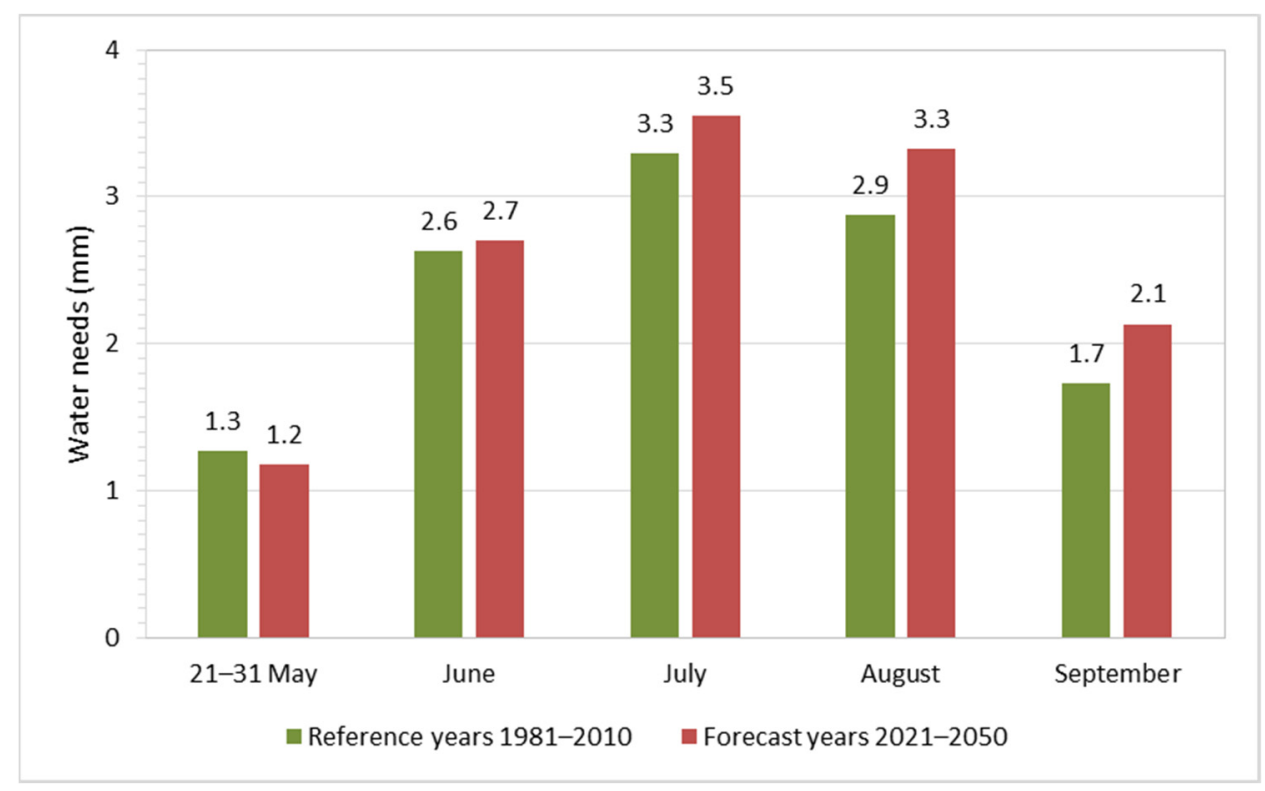

Figure 2. Mean daily water needs of giant miscanthus in the intensive growth season in the reference (1981-2010) and forecast (2021-2050) years.

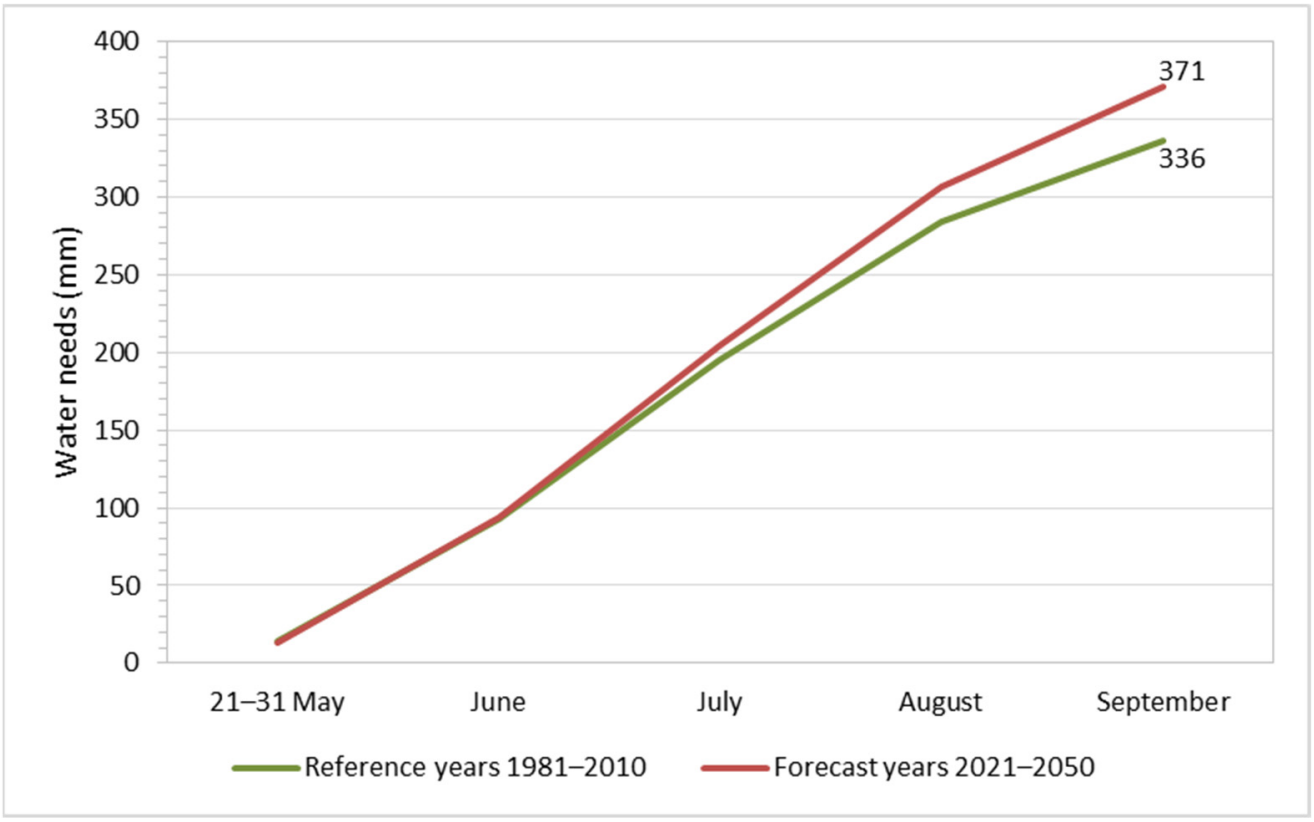

Figure 3. Cumulative water needs of giant miscanthus in the intensive growth season in the reference (1981-2010) and forecast (2021-2050) years.

Table 5. Water needs (mm) of giant miscanthus during its specific spells of growth in the reference (1981-2010) and forecast (2021-2050) years.

\begin{tabular}{|c|c|c|c|c|c|c|c|c|}
\hline \multirow{2}{*}{\multicolumn{2}{|c|}{ Period }} & \multicolumn{7}{|c|}{ Spell of Growth } \\
\hline & & 21-31 May & 1-30 June & 1-31 July & $\begin{array}{c}\text { 1-31 } \\
\text { August }\end{array}$ & $\begin{array}{c}1-30 \\
\text { September }\end{array}$ & $\begin{array}{l}1 \text { June-31 } \\
\text { August }\end{array}$ & $\begin{array}{l}21 \text { May-30 } \\
\text { September }\end{array}$ \\
\hline \multirow{2}{*}{\multicolumn{2}{|c|}{$\begin{array}{c}\text { Reference (A) } \\
\text { Forecast (B) }\end{array}$}} & 14 & 79 & 102 & 89 & 52 & 270 & 336 \\
\hline & & 13 & 81 & 110 & 103 & 64 & 294 & 371 \\
\hline Difference & $(\mathrm{mm})$ & -1 & 2 & 8 & 14 & 12 & 24 & 35 \\
\hline $\mathrm{B}-\mathrm{A}$ & $(\%)$ & -7 & +3 & +8 & +16 & +23 & +9 & +10 \\
\hline
\end{tabular}




\section{Discussion}

In the present research the water needs of giant miscanthus grown in the Kuyavia region situated in central Poland (central Europe) were determined. The water needs, calculated in the intensive growth season of giant miscanthus, considered from 21 May to 30 September, amounted to $336 \mathrm{~mm}$ in the thirty-year reference period (1981-2010) and $371 \mathrm{~mm}$ in the thirty-year forecast period (2021-2050). Previous reports assessing the giant miscanthus water needs show much higher values. According to Żyromski, et al. $[10,11]$ in the giant miscanthus cultivation, the annual sum of precipitations should be around $600-700 \mathrm{~mm}$. Such amounts of water, according to us, fully cover the water needs of miscanthus in climatic conditions of central Poland. However, due to the wellknown fact that giant miscanthus is a plant with relatively low water requirements [30], the above results may seem imprecise. Much more reliable seems to be the effects of the field experiment published by Żyromski, et al. [9], where in the years 2011-2013, the precipitation conditions during the summer half-years that covered the growing season of giant miscanthus, corresponded to the wet periods in 2011 and 2012 with the rainfall totals amounting to $453.8 \mathrm{~mm}$ and $427.6 \mathrm{~mm}$, respectively, while the same period in 2013 was very wet with the rainfall total amounting to $541.3 \mathrm{~mm}$.

The current research is the first to estimate the water needs of giant miscanthus in central Poland in the years 2021-2050, taking into account the projected climate changes, mainly the rise of air temperature. The increase in the giant miscanthus water needs, calculated in the present study, is the result of only the rise in air temperature, which results from the adopted methodological assumptions. This study based on the forecast values of average monthly air temperature for the Kuyavia region in the years 2021-2050 according to the climate change scenario SRES: A1B, is considered to be one of the most probable for this area of Poland $[49,50]$. Air temperature is one of the main meteorological factors influencing the evapotranspiration of plants directly by influencing the process of water vapor diffusion [51]. In the present study, during the calculations of reference evapotranspiration for the forecast period 2021-2050, other major meteorological factors affecting the evapotranspiration, such as solar radiation, sunshine, air humidity, and wind speed, were not taken into account. It was assumed that, by extrapolating the relationship between air temperature and reference evapotranspiration, the nature of the relationship between them would not change. Similar methodological assumptions were adopted in the studies reported by Łabędzki, et al. [55,57]. The present research also adopted the assumption that under the conditions of climate change in the future, the crop coefficient will not change. Although, in the light of the current knowledge, there are no reliable premises and no research indicating that both the relationship between air temperature and reference evapotranspiration, as well the values of crop coefficient will not change under the conditions of climate change $[51,52,55]$.

A possible increase in water deficits in agriculture, as a result of climate change, may increase the current trends in the development of irrigation. It is expected that in Poland, along with the negative effects of climate change, crop water needs will increase and subsequently the importance of irrigation in agriculture should increase [55].

The increase in water needs of miscanthus predicted for the years 2021-2050 in our study (as a result of the expected increase in air temperature in the summer), combined with the forecast decrease in rainfall in this period $[49,50]$ and the extension of the growing season, may reduce the available water resources in the soil, increase water scarcity for plants, and finally reduce actual water consumption by plants. Therefore, it is expected that there will be a rapid decrease in soil moisture during the growing season. For example, according to the ECHAM5 model, it is expected that the average annual values of soils mobile water retention will decrease by approximately $7 \%$ over 50 years; however, according to the GFDL model, the projected changes may amount to 15\% [58]. This may evidence, among others, that an increase in frequency of dry years and, consequently, a significant reduction in amounts of soil water available for plants, e.g., miscanthus may occur in the near future. 
Mean daily rates of water use by rainfed giant miscanthus were found to be less than $2.5 \mathrm{~mm} \mathrm{~d}^{-1}$. In irrigated crops the values were greater at about $3.4 \mathrm{~mm} \mathrm{~d}^{-1}$, giving an annual water use of between $250 \mathrm{~mm}$ and $450 \mathrm{~mm}$ depending upon the availability of water $[59,60]$. Over the growing season in Italy from mid-April to the end of September, irrigated miscanthus used between 360 and $620 \mathrm{~mm}$ [59-61].

The results of the research carried out in central Poland by Jurczuk and Rydałowski [62] on the miscanthus plantation of 6 ha in 2008-2009 are similar to the values obtained in our study. Water use from April to September (with soil moisture around field water capacity) was $355 \mathrm{~mm}$ in 2008 and $440 \mathrm{~mm}$ in 2009. Precipitation totals equaled $333 \mathrm{~mm}$ and $502 \mathrm{~mm}$ respectively. Furthermore, the study of Hamilton et. al. [63] conducted in the north-eastern part of United States of America (US) from May to September in 2010-2014 shows miscanthus average water use at $458( \pm 31) \mathrm{mm}$.

In climatic conditions of central Italy [12], on the basis of lysimeter experiments at stable water table depth $(0.8 \mathrm{~m})$ carried out in 2010-2011, the average water consumption by miscanthus expressed as evapotranspiration was $882 \mathrm{~mm}$. In the examined years the values of kc were in the range of $0.31-0.64$ in initial development stages (April-May) and in the range of 1.20-1.61 in the mid-season (June-August). Such big values of kc could result from high ET measured in lysimeters (even $10.7 \mathrm{~mm} \mathrm{~d}^{-1}$ ). In the current study we used the crop coefficients that can represent the average conditions within a multiyear period.

On the basis of field experiments on 6 ha plantation of miscanthus located in Wales, Holder, et. al. [13] proposed the following values of kc: 0.63 for the early season (March and April) and 0.85 for the main growing season (May to September). The crop coefficients were calculated on the basis of the eddy covariance data and the Penman-Monteith method.

The impact of climate change scenarios projected for miscanthus evapotranspiration until 2050 studied for the mid-western US [64] show similar values to the results presented in the current study. Air temperature increase by $2{ }^{\circ} \mathrm{C}$ will increase total evapotranspiration by $19 \mathrm{~mm}$.

The increase in the giant miscanthus water needs, found in the present study, confirms the results obtained for other plant species such as grapevine $[65,66]$ or potato [55]. According to Kowalik and Scalenghe [67], the water needs of the crops focused on biomass production are 2-3 times lower in Poland compared to southern Europe. However, it is expected that soon in Poland the water requirements of energy crops will be $20-30 \%$ higher than in the case of other crops that will require supplementary irrigation of plants [67].

It seems advisable to continue the analysis of the water needs of other energy plant species, both in the Kuyavia region and the other areas across Poland. The co-authors of this study determined, in lysimeter investigations in Poland, crop coefficient values for such energy plant species as Virginia mallow, Jerusalem artichoke and willow [9]. This makes it possible to estimate the water needs of energy plants in different regions of Poland, taking into account the predicted climate changes. The analysis of Ostrowski, et al. [68] indicates that in Poland, an area of up to 2.2 million hectares can be designated for plantations of energy crops (including part of the existing grasslands).

A more recent analysis by Ostrowski and Gutkowska [69] indicates that about 1.4 million ha of arable land in Poland can be allocated for energy plants cultivation, instead of melioration or rebuilding the devalued drainage systems. Assuming the obtaining of an average yield of biomass amounting to $10 \mathrm{t} \mathrm{ha}^{-1}$ and the alternative use of approx. $80 \%$ of selected grounds, can be annually gain about 10 million tons of renewable energy resource, accumulating about $7 \times 10^{6} \mathrm{GJ}$ of energy, whereas adopting a unit cost of drainage indicatively 20,000 PLN per ha saves about 25 billion PLN of investment funds in agriculture. The analysis of the relationship between the agricultural usefulness of soils and the habitat requirements of energy plants (including the giant miscanthus) performed by the same authors [68] shows that at the area of Kuyavian-Pomeranian province about $6 \%$ of arable land (an area of 65,000 ha) can be used for energy plants cultivation.

Although giant miscanthus prefers well-hydrated soils, especially in the first year of cultivation, it yields equally well on moderately moist soils [69]. The results obtained in 
our study may therefore contribute to the rational management of plant energy resources. The presented research facilitates the identification of the possibility of obtaining the giant miscanthus biomass, thanks to the determination of its water needs in potential areas of its production (Kuyavia region, central Poland) without compromising the food needs of this region of Poland. The current study may also contribute to increasing the efficiency of water use in this area and lead to the improvement of possible irrigation, minimizing its negative impact on the natural environment [67]. In fact, giant miscanthus is generally associated with positive impact on the environment through advantageous health effects on ecosystems. Plants of this species effectively protect the soil against wind and water erosion. Additionally, by increasing the content of organic matter, the cultivation of giant miscanthus plants may contribute to the improvement of soil quality [70].

\section{Conclusions}

In the forecast years 2021-2050, as a result of the projected climate changes-mainly an increase in air temperature-the water needs of giant miscanthus, expressed by potential evapotranspiration, will increase. In the growing season of this crop, considered from 21 May to 30 September, the increase in its water needs, will amount to $35 \mathrm{~mm}$ (over $10 \%$ ). The highest monthly increase in the giant miscanthus water needs may occur in August (by $14 \mathrm{~mm}$, i.e., by 16\%) and September (by $12 \mathrm{~mm}$, i.e., by 23\%). The expected climate changes, and consequently the increase in water requirements by energy crops, will cause an increase in irrigated areas in the Kuyavia region (central Poland), where there is currently the highest requirement for supplementary irrigation. Summing up, the presented research results show that the observed climate changes clearly affect the increase in water needs of miscanthus, which will necessitate the use of supplementary and rational irrigation of this species. In the future, toward adaptation of agriculture to climate change, the results of the present research may contribute to the development of the appropriate management of irrigation treatments and plant energy resources in this region. The results of the current study may also contribute to increasing the water use efficiency and minimize their negative impact on the natural environment in the Kuyavia region in central Poland and other areas located in the temperate warm, transitory climatic zone.

Author Contributions: Conceptualization, S.R., M.B.-P., A.Ż.; R.R. and P.S.; methodology, S.R., M.B.P., A.Ż.; W.K.-W.; R.R. and P.S.; software, S.R. and R.R.; validation, S.R., P.S. and F.P.-F.; formal analysis, S.R., A.Ż. and F.P.-F.; investigation, S.R., R.R. and D.L.; resources, S.R., A.Ż., W.K.-W., E.K.-G. and R.R.; data curation, S.R., E.K.-G., R.R., W.P. and D.L.; writing-original draft preparation, S.R., M.B.-P., A.Ż., W.P., B.J., W.K.-W., E.K.-G., R.R., P.S., D.L. and H.A.S.; writing-review and editing, S.R., M.B.-P., A.Ż., B.J., W.K.-W., E.K.-G., R.R., P.S., W.P. and H.A.S.; visualization, S.R., W.K.-W., B.J., R.R., D.L. and H.A.S.; supervision, S.R., M.B.-P., W.K.-W.; B.J., R.R. and F.P.-F.; project administration, S.R.; funding acquisition, S.R., All authors have read and agreed to the published version of the manuscript.

Funding: This research received no external funding.

Institutional Review Board Statement: Not applicable.

Informed Consent Statement: Not applicable.

Data Availability Statement: Data sharing not applicable.

Conflicts of Interest: The authors declare no conflict of interest.

\section{References}

1. Malhi, G.S.; Kaur, M.; Kaushik, P. Impact of climate change on agriculture and its mitigation strategies: A review. Sustainability 2021, 13, 1318. [CrossRef]

2. European Environment Agency. Climate Change Adaptation in the Agriculture Sector in Europe; EEA Report No 04; European Environment Agency: Copenhagen, Denmark, 2019; ISBN 9789294800725. 
3. Food and Agriculture Organization of the United Nations. The Future of Food and Agriculture. Alternative Pathways to 2050; FAO: Roma, Italy, 2018.

4. Kundzewicz, Z.W.; Matczak, P. Climate change regional review: Poland. Wiley Interdiscip. Rev. Clim. Chang. 2012, 3, $297-311$. [CrossRef]

5. Zeri, M.; Hussain, M.Z.; Anderson-Teixeira, K.J.; DeLucia, E.; Bernacchi, C.J. Water use efficiency of perennial and annual bioenergy crops in central Illinois. J. Geophys. Res. Biogeosci. 2013, 118, 581-589. [CrossRef]

6. Zhao, X.; Kang, L.; Wang, Q.; Lin, C.; Liu, W.; Chen, W.; Sang, T.; Yan, J. Water use efficiency and stress tolerance of the potential energy crop Miscanthus lutarioriparius grown on the Loess Plateau of China. Plants 2021, 10, 544. [CrossRef] [PubMed]

7. Podlaski, S.; Pietkiewicz, S.; Chołuj, D.; Horaczek, T.; Wiśniewski, G.; Gozdowski, D.; Kalaji, H.M. The relationship between the soil water storage and water-use efficiency of seven energy crops. Photosynthetica 2017, 55, 210-218. [CrossRef]

8. VanLoocke, A.; Twine, T.E.; Zeri, M.; Bernacchi, C.J. A regional comparison of water use efficiency for miscanthus, switchgrass and maize. Agric. For. Meteorol. 2012, 164, 82-95. [CrossRef]

9. Żyromski, A.; Biniak-Pieróg, M.; Szulczewski, W.; Kordas, L.; Kabała, C.; Gałka, B. Mathematical Modeling of Evapotranspiration of Selected Energy Crops; UP: Wrocław, Poland, 2016; pp. 1-158.

10. Żyromski, A.; Szulczewski, W.; Biniak-Pieróg, M.; Okrasińska, H. Prosty model ewapotranspiracji dla wybranych roślin energetycznych [Simple model of evapotranspiration of selected energy plants]. Woda-Sr.-Obsz. Wiej. 2012, 12, 391-399.

11. Żyromski, A.; Szulczewski, W.; Biniak-Pieróg, M.; Okrasińska, H. Zastosowanie modelu WSMT do oceny ewapotranspiracji miskanta i topinamburu [WSMT model application for topinambour and giant Chinese silver grass evapotranspiration estimation]. Woda-Sr.-Obsz. Wiej. 2012, 12, 401-409.

12. Triana, F.; Nassi o Di Nasso, N.; Ragaglini, G.; Roncucci, N.; Bonari, E. Evapotranspiration, crop coefficient and water use efficiency of giant reed (Arundo donax L.) and miscanthus (Miscanthus $\times$ giganteus Greef et Deu.) in a Mediterranean environment. GCB Bioenergy 2015, 7, 811-819. [CrossRef]

13. Holder, A.J.; McCalmont, J.P.; McNamara, N.P.; Rowe, R.; Donnison, I.S. Evapotranspiration model comparison and an estimate of field scale Miscanthus canopy precipitation interception. GCB Bioenergy 2018, 10, 353-366. [CrossRef]

14. Ings, J.; Mur, L.A.J.; Robson, P.R.H.; Bosch, M. Physiological and growth responses to water deficit in the bioenergy crop Miscanthus x giganteus. Front. Plant Sci. 2013, 4, 468. [CrossRef]

15. De Vega, J.J.; Teshome, A.; Klaas, M.; Grant, J.; Finnan, J.; Barth, S. Physiological and transcriptional response to drought stress among bioenergy grass Miscanthus species. Biotechnol. Biofuels 2021, 14, 60. [CrossRef] [PubMed]

16. Emerson, R.; Hoover, A.; Ray, A.; Lacey, J.; Cortez, M.; Payne, C.; Karlen, D.; Birrell, S.; Laird, D.; Kallenbach, R.; et al. Drought effects on composition and yield for corn stover, mixed grasses, and Miscanthus as bioenergy feedstocks. Biofuels 2014, 5, 275-291. [CrossRef]

17. Van der Weijde, T.; Huxley, L.M.; Hawkins, S.; Sembiring, E.H.; Farrar, K.; Dolstra, O.; Visser, R.G.F.; Trindade, L.M. Impact of drought stress on growth and quality of miscanthus for biofuel production. GCB Bioenergy 2017, 9, 770-782. [CrossRef]

18. Scordia, D.; Cosentino, S. Perennial energy grasses: Resilient crops in a changing European agriculture. Agriculture 2019, 9, 169. [CrossRef]

19. Brosse, N.; Dufour, A.; Meng, X.; Sun, Q.; Ragauskas, A. Miscanthus: A fast-growing crop for biofuels and chemicals production. Biofuels Bioprod. Biorefining 2012, 6, 580-598. [CrossRef]

20. Heaton, E.A.; Dohleman, F.G.; Miguez, A.F.; Juvik, J.A.; Lozovaya, V.; Widholm, J.; Zabotina, O.A.; McIsaac, G.F.; David, M.B.; Voigt, T.B.; et al. Miscanthus. A promising biomass crop. In Advances in Botanical Research; Academic Press Inc.: Cambridge, MA, USA, 2010; Volume 56, pp. 75-137.

21. Witzel, C.P.; Finger, R. Economic evaluation of miscanthus production-A review. Renew. Sustain. Energy Rev. 2016, 53, 681-696. [CrossRef]

22. Dhillon, R.S.; von Wuehlisch, G. Mitigation of global warming through renewable biomass. Biomass Bioenergy 2013, 48, 75-89. [CrossRef]

23. Shepherd, A.; Littleton, E.; Clifton-Brown, J.; Martin, M.; Hastings, A. Projections of global and UK bioenergy potential from Miscanthus $\times$ giganteus -Feedstock yield, carbon cycling and electricity generation in the 21st century. GCB Bioenergy 2020, 12, 287-305. [CrossRef]

24. Heaton, E.A.; Dohleman, F.G.; Long, S.P. Meeting US biofuel goals with less land: The potential of Miscanthus. Glob. Chang. Biol. 2008, 14, 2000-2014. [CrossRef]

25. Dubis, B.; Jankowski, K.J.; Załuski, D.; Bórawski, P.; Szempliński, W. Biomass production and energy balance of Miscanthus over a period of 11 years: A case study in a large-scale farm in Poland. GCB Bioenergy 2019, 11, 1187-1201. [CrossRef]

26. Lewandowski, I.; Clifton-Brown, J.C.; Scurlock, J.M.O.; Huisman, W. Miscanthus: European experience with a novel energy crop. Biomass Bioenergy 2000, 19, 209-227. [CrossRef]

27. Xue, S.; Kalinina, O.; Lewandowski, I. Present and future options for miscanthus propagation and establishment. Renew. Sustain. Energy Rev. 2015, 49, 1233-1246. [CrossRef]

28. Arnoult, S.; Brancourt-Hulmel, M. A Review on miscanthus biomass production and composition for bioenergy use: Genotypic and environmental variability and implications for breeding. Bioenergy Res. 2015, 8, 502-526. [CrossRef]

29. Szulczewski, W.; Żyromski, A.; Jakubowski, W.; Biniak-Pieróg, M. A new method for the estimation of biomass yield of giant miscanthus (Miscanthus giganteus) in the course of vegetation. Renew. Sustain. Energy Rev. 2018, 82, 1787-1795. [CrossRef] 
30. Strašil, Z. Evaluation of miscanthus grown for energy use. Res. Agric. Eng. 2016, 62, 92-97. [CrossRef]

31. Mazur, A.; Kowalczyk-Juśko, A. The assessment of the usefulness of Miscanthus $\times$ giganteus to water and soil protection against erosive degradation. Resources 2021, 10, 66. [CrossRef]

32. Kharytonov, M.; Pidlisnyuk, V.; Stefanovska, T.; Babenko, M.; Martynova, N.; Rula, I. The estimation of Miscanthus $\times$ giganteus' adaptive potential for cultivation on the mining and post-mining lands in Ukraine. Environ. Sci. Pollut. Res. 2019, 26, 2974-2986. [CrossRef]

33. Wang, C.; Kong, Y.; Hu, R.; Zhou, G. Miscanthus: A fast-growing crop for environmental remediation and biofuel production. GCB Bioenergy 2021, 13, 58-69. [CrossRef]

34. Nurzhanova, A.; Pidlisnyuk, V.; Abit, K.; Nurzhanov, C.; Kenessov, B.; Stefanovska, T.; Erickson, L. Comparative assessment of using Miscanthus $\times$ giganteus for remediation of soils contaminated by heavy metals: A case of military and mining sites. Environ. Sci. Pollut. Res. 2019, 26, 13320-13333. [CrossRef]

35. Gizińska-Górna, M.; Jóźwiakowski, K.; Marzec, M. Reliability and efficiency of pollutant removal in four-stage constructed wetland of SSVF-SSHF-SSHF-SSVF type. Water 2020, 12, 3153. [CrossRef]

36. Nsanganwimana, F.; Pourrut, B.; Mench, M.; Douay, F. Suitability of miscanthus species for managing inorganic and organic contaminated land and restoring ecosystem services. A review. J. Environ. Manag. 2014, 143, 123-134. [CrossRef] [PubMed]

37. Mehmood, M.A.; Ibrahim, M.; Rashid, U.; Nawaz, M.; Ali, S.; Hussain, A.; Gull, M. Biomass production for bioenergy using marginal lands. Sustain. Prod. Consum. 2017, 9, 3-21. [CrossRef]

38. Pidlisnyuk, V.; Stefanovska, T.; Lewis, E.E.; Erickson, L.E.; Davis, L.C. Miscanthus as a productive biofuel crop for phytoremediation. Criti. Rev. Plant Sci. 2014, 33, 1-19. [CrossRef]

39. Kuś, J.; Matyka, M. Uprawa Roślin na cele Energetyczne. Instrukcja Upowszechnieniowa nr 179 [Growing Plants for Energy Purposes. Dissemination Instruction No. 179]; IUNG-PIB: Puławy, Poland, 2010; p. 64.

40. Stolarski, J.M.; Śnieg, M.; Krzyżaniak, M.; Tworkowski, J.; Szczukowski, S. Short rotation coppices, grasses and other herbaceous crops: Productivity and yield energy value versus 26 genotypes. Biomass Bioenergy 2018, 119, 109-120. [CrossRef]

41. Cichosz, S.; Gośka, M.; Litwiniec, A. Trawy wieloletnie z rodzaju Miscanthus—potencjalne źródło energii odnawialnej [Perennial grasses of the genus Miscanthus-A potential source of renewable energy]. Biul. Inst. Hod. Aklim. Rośl. 2014, 274, 133-151.

42. Jezierska-Thöle, A.; Rudnicki, R.; Kluba, M. Development of energy crops cultivation for biomass production in Poland. Renew. Sustain. Energy Rev. 2016, 62, 534-545. [CrossRef]

43. Van der Weijde, T.; Alvim Kamei, C.L.; Torres, A.F.; Vermerris, W.; Dolstra, O.; Visser, R.G.F.; Trindade, L.M. The potential of C4 grasses for cellulosic biofuel production. Front. Plant Sci. 2013, 4, 107. [CrossRef]

44. Lewandowski, I.; Clifton-Brown, J.; Kiesel, A.; Hastings, A.; Iqbal, Y. Miscanthus. In Perennial Grasses for Bioenergy and Bioproducts; Alexopoulou, E., Ed.; Academic Press: London, UK, 2018; pp. 35-59.

45. Matyka, M.; Kuś, J. Influence of soil quality for yielding and biometric features of Miscanthus x Giganteus. Pol. J. Environ. Stud. 2016, 25, 213-219. [CrossRef]

46. Ben Fradj, N.; Rozakis, S.; Borzecka, M.; Matyka, M. Miscanthus in the European bio-economy: A network analysis. Ind. Crops Prod. 2020, 148, 112281. [CrossRef]

47. Zastosowanie Miskanta Olbrzymiego Jako Rośliny Energetycznej-Ogrzewnictwo [The use of Giant Miscanthus as an Energy Plant-Heating]. Available online: www.ogrzewnictwo.pl (accessed on 1 December 2020).

48. Błażejczyk, K.; Kasperska-Wołowicz, W.; Łabędzki, L.; Kunert, A. Multi-annual fluctuations in precipitation and their hydrological and ecological consequences at regional scale. In Regional Hydrological Impacts of Climatic Change—Hydroclimatic Variability; IAHS Series of Proceedings and Reports: IAHS Publication 296; IAHS Publish: Oxfordshire, UK, 2005; Volume 296, pp. 65-70.

49. Bak, B.; Łabędzki, L. Prediction of precipitation deficit and excess in Bydgoszcz region in view of predicted climate change. J. Water Land Dev. 2014, 23, 11-19. [CrossRef]

50. Bąk, B.; Łabędzki, L. Thermal conditions in Bydgoszcz region in growing seasons 2011-2050 in view of expected climate change. J. Water Land Dev. 2014, 23, 21-29. [CrossRef]

51. Łabędzki, L.; Szajda, J.; Szuniewicz, J. Ewapotranspiracja Upraw Rolniczych-Terminologia, Definicje, Metody Obliczania-Przeglad Stanu Wiedzy [Evapotranspiration of Agricultural Crops-Terminology, Definitions, Calculation Methods. Review]; IMUZ: Falenty, Poland, 1996; Volume 33, pp. 1-15.

52. Łabędzki, L. Susze rolnicze. Zarys problematyki oraz metody monitorowania i klasyfikacji [Agricultural droughts. An outline of problems and methods of monitoring and classification]. In Woda-Środowisko-Obszary Wiejskie [Water-Environment-Rural Areas]; Rozprawy Naukowe i Monografie [Scientific Disser-tations and Monographs]; IMUZ: Falenty, Poland, 2006; Volume 17, pp. 1-107.

53. Allen, R.G.; Pereira, L.S.; Raes, D.; Smith, M. Evapotranspiration. Guidelines for Computing Crop Water Requirements; FAO Irrigation and Drainage Paper 56; Food and Agriculture Organization: Rome, Italy, 1998.

54. Łabędzki, L.; Kanecka-Geszke, E.; Bąk, B.; Słowińska, S. Estimation of reference evapotranspiration using the FAO PenmanMonteith method for climatic conditions of Poland. In Evapotranspiration; Łabędzki, L., Ed.; InTech: Rijeka, Croatia, 2011; pp. 275-294.

55. Łabędzki, L.; Bąk, B.; Liszewska, M. Wpływ przewidywanej zmiany klimatu na zapotrzebowanie ziemniaka późnego na wodę [Impact of climate change on water needs of late potato]. Infrastruct. Ecol. Rural Areas 2013, 2, 155-165.

56. Platt, C. Problemy Rachunku Prawdopodobieństwa i Statystyki Matematycznej [Probability Theory and Mathematical Statistics]; PWN: Warszawa, Poland, 1978. 
57. Łabędzki, L.; Bąk, B.; Kanecka-Geszke, E.; Kasperska-Wołowicz, W.; Smarzyńska, K. Związek między suszą meteorologiczną i rolniczą $w$ różnych regionach agroklimatycznych Polski [The relationship between meteorological and agricultural droughts in various agroclimatic regions of Poland]. In Woda-Środowisko-Obszary Wiejskie [Water-Environment-Rural Areas]; Rozprawy Naukowe i Monografie [Scientific Dissertations and Monographs]; IMUZ: Falenty, Poland, 2008; Volume 25, pp. 1-137.

58. Somorowska, U. Dynamika glebowych zasobów wodnych w Polsce współcześnie i w przyszłości [Dynamics of soil water resources in Poland today and in the future]. Prz. Geof. 2008, 2, 155-165.

59. Stephens, W.; Hess, T.; Knox, J. Review of the Effects of Energy Crops on Hydrology; Institute of Water and Environment, Cranfield University Silsoe: Bedford, UK, 2001.

60. Beale, C.V.; Morison, J.I.L.; Long, S.P. Water use efficiency of C4 perennial grasses in a temperate climate. Agric. For. Meteorol. 1999, 96, 103-115. [CrossRef]

61. Ercoli, L.; Mariotti, M.; Mansoni, A.; Bonari, E. Effect of irrigation and nitrogen fertilization on biomass yield and efficiency of energy use in crop production of Miscanthus. Field Crops Res. 1999, 63, 3-11. [CrossRef]

62. Jurczuk, S.; Rydałowski, M. Polowe zużycie wody na plantacjach wierzby wiciowej i miskanta olbrzymiego [Field water consumption in plantations of the common osier and giant miscanthus]. In Modelowanie Energetycznego Wykorzystania Biomasy [Modeling of Energy Use of Biomass]; Grzybek, A., Ed.; ITP: Falenty-Warszawa, Poland, 2010; pp. 92-101.

63. Hamilton, S.K.; Hussain, M.Z.; Bhardwaj, A.K.; Basso, B.; Robertson, G.P. Comparative water use by maize, perennial crops, restored prairie, and poplar trees in the US Midwest. Environ. Res. Lett. 2015, 10, 064015. [CrossRef]

64. Le, P.V.V.; Kumar, P.; Drewry, D.T. Implications for the hydrologic cycle under climate change due to the expansion of bioenergy crops in the Midwestern United States. Proc. Natl. Acad. Sci. USA 2011, 108, 15085-15090. [CrossRef] [PubMed]

65. Jagosz, B.; Rolbiecki, S.; Stachowski, P.; Ptach, W.; Łangowski, A.; Kasperska-Wołowicz, W.; Sadan, A.H.; Rolbiecki, R.; Prus, P.; Kazula, M. Assessment of water needs of grapevines in western Poland from the perspective of climate change. Agriculture 2020, 10, 477. [CrossRef]

66. Jagosz, B.; Rolbiecki, S.; Rolbiecki, R.; Łangowski, A.; Sadan, H.A.; Ptach, W.; Stachowski, P.; Kasperska-Wołowicz, W.; Pal-Fam, F.; Liberacki, D. The water needs of grapevines in central Poland. Agronomy 2021, 11, 416. [CrossRef]

67. Kowalik, P.; Scalenghe, R. Potrzeby wodne roślin energetycznych jako problem oddziaływania na środowisko w Polsce [Water needs of energy crops-One of the environmental problems of Poland]. In Polska Inżynieria Środowiska pięć lat po Wstapieniu do Unii Europejskiej [Polish Environmental Engineering Five Years after Joining the European Union]; Dudzińska, M., Pawłowski, L., Eds.; Komitet Inżynierii Środowiska PAN: Lublin, Poland, 2009; Volume 3, pp. 61-69.

68. Ostrowski, J.; Gutkowska, A.; Tusiński, E. Udział czynnika wodnego w modelu kategoryzacji oraz oceny przydatności gruntów do uprawy roślin energetycznych [The role of water factor in modelling categorisation and evaluation of land usefulness for cultivation of energetic crops]. Woda-Sr.-Obsz. Wiej. 2009, 9, 187-202.

69. Ostrowski, J.; Gutkowska, A. Modelowanie oceny alternatywnego zagospodarowania zmeliorowanych gruntów ornych pod uprawę roślin energetycznych [Assessment modeling of alternative use of meliorated arable land for the cultivation of energy crops]. Woda-Sr.-Obsz. 2016, 45, 1-176.

70. Blanco-Canqui, H. Energy crops and their implications on soil and environment. Agron. J. 2010, 102, 403-419. [CrossRef] 